\title{
PERHITUNGAN KEBIJAKAN INSENTIF PAJAK PENGHASILAN DI MASA PANDEMI COVID-19
}

Oleh :

Gede Ngurah Indra Arya Aditya

Program Studi Akuntansi Fakultas Ekonomi dan Bisnis, Universitas Pendidikan Nasional Bali Email : indraaditya@undiknas.ac.id

\begin{tabular}{l}
\hline Article Info \\
\hline Article History : \\
Received 29 August - 2021 \\
Accepted O7 Sept - 2021 \\
Available Online 25 Sept- \\
2021
\end{tabular}

Keyword:

Covid-19, Tax Incentives, Article 21 Income Tax, Pandemic.

\begin{abstract}
Indonesia has officially declared that the Covid-19 pandemic has been declared a non-natural national disaster. This is stated through Presidential Regulation of the Republic of Indonesia Number 12 of 2020. Of course, when facing a pandemic period, taxpayers get the right to benefits because they have overcome the Covid-19 problem through tax donations given. The government will issue a fiscal stimulus policy in the relaxation of Article 21 Income Tax with certain criteria regulated in the Regulation of the Minister of Finance of the Republic of Indonesia Number 44/PMK.03/2020 concerning Tax Incentives for Taxpayers Affected by the 2019 Virus Disease Pandemic (Covid-19) Corona Tax. This study uses quantitative and qualitative data sourced from scientific articles, tax laws and regulations, as well as theoretical books and procedures for calculating PPh Article 21 during the Covid-19 pandemic in Indonesia which can be used as the basis for ongoing research. Direct observation of the object of research, namely Taxpayers (WP) who get Income Tax Incentives (PPh) Article 21. The results of this research are to help the general public and in particular individual taxpayers to be able to independently calculate Article $21 \mathrm{PPh}$, especially to ensure whether Taxpayers can get Income Tax Incentives that can help ease the economic burden affected by the spread of Covid-19 in Indonesia. The government in terms of providing tax incentives has an impact on reducing state revenues from the tax sector, but this policy can help reduce the domino effect due to the Covid-19 pandemic on the national economy.
\end{abstract}

\section{PENDAHULUAN}

Penyebaran virus Covid-19 yang telah terjadi di Indonesia langsung memberikan dampak buruk bagi seluruh kegiatan perekonomian di Indonesia. Pemerintah Indonesia telah menetapkan hal ini sebagai bencana tingkat nasional non-alam, melalui Keputusan Presiden Republik Indonesia Nomor 12 Tahun 2020. Keputusan Presiden ini mengatur mengenai pelaksanaan penanggulangan Covid-19 dimana peta penyebaran Covid-19 di Indonesia (Fitri, 2020). Pandemi covid-19 ini telah mengakibatkan menurunnya ketahanan ekonomi nasional dimana terjadi evaluasi dan deregulasi yang cukup signifikan. Salah satu yang dapat menjadi penopang untuk ekonomi nasional salah satunya adalah dari sektor pajak (Aqmarina, 2020). Pemungutan pajak bukan sekedar kewajiban bagi masyarakat namun juga terdapat hak dari masyarakat yang melekat, dimana dari penerimaan pajak dapat dipergunakan untuk memperkuat ketahanan ekonomi nasional pada Pemerintahan pusat maupun daerah (Rahman, 
2018). Sumber penerimaan yang telah diterima oleh negara harus dikelola dengan mengutamakan kesejahteraan bagi masyarakat. Sumber pendapatan merupaka hak dari Pemerintah pusat yang akan diakui sebagai penambahan kekayaan bersih, dimana terdiri dari seluruh jenis penerimaan pajak, adapun salah satu bentuk klasfikasi pajak adalah pemungutan pajak penghasilan $(\mathrm{PPh})$ yang akan dibahas dalam penulisan ini.

Akibat pandemi Covid-19 pemerintah sebagai pengambil kebijakan memberikan beberapa stimulus perekonomian untuk dapat menyeimbangkan dengan efek domino terhadap dampak pandemi Covid-19 (Hs et al., 2020), diantaranya adalah paket stimulus fiskal dalam hal melakukan relaksasi pada Pajak Penghasilan (PPh) Pasal 21. Stimulus fiskal dalam relaksasi $\mathrm{PPh}$ Pasal 21 hanya berlaku untuk penghasilan pekerja atau pegawai dengan kriteria tertentu yang telah di tetapkan dalam Peraturan Menteri Keuangan Republik Indonesia Nomor 44/PMK.03/2020 Tentang Insentif Pajak Untuk Wajib Pajak Terdampak Pandemi Corona Virus Disease 2019 (Covid-19) perubahan dari Peraturan Menteri Keuangan Nomor 23/PMK.03/2020. Pegawai dengan kreteria tertentu tersebut (Wiryawan, 2019), meliputi: 1. Menerima atau memperoleh penghasilan dari Pemberi Kerja, yang: (a) Memiliki kode Klasifikasi Lapangan Usaha (KLU) sesuai dengan Peraturan Menteri Keuangan No. 44/PMK.03/2020, (b) Telah ditetapkan sebagai Perusahaan Kemudahan Impor Tujuan Ekspor (KITE), atau (c) Telah mendapatkan izin Penyelenggaraan Kawasan Berikat, izin Pengusaha Kawasan Berikat, atau izin Pengusaha Dalam Kawasan Berikat (PDKB); 2. Memiliki Nomor Pokok Wajib Pajak (NPWP); 3. Pada Masa Pajak yang bersangkutan menerima atau memperoleh Penghasilan Bruto yang bersifat tetap dan teratur yang disetahunkan tidak lebih dari Rp. 200.000.000,(dua ratus juta rupiah).

Menurut Azra (Pendit et al., 2017) Mengacu kepada UU 17/2003 mengenai Keuangan Negara, pendapatan negara merupakan seluruh penerimaan yang berasal tidak hanya dari bidang perpajakan, tetapi termasuk pendapatan negara yang bukan dalam kategori pajak serta dalam bentuk hibah sebagai penerimaan negara yang bersumber dari dalam dan dari luar negeri (Ayza, 2017).

Pada karya penulisan ini mempunyai tujuan untuk membantu masyarakat umum dan khususnya wajib pajak orang pribadi untuk dapat menghitung pajak penghasilan Pasal 21 secara mandiri, terutama untuk memastikan apakah wajib pajak dapat memperoleh Insentif Pajak Penghasilan yang dapat membantu meringankan beban ekonomi yang dipengaruhi oleh penyebaran Covid-19 di Indonesia.

\section{KAJIAN PUSTAKA DAN Pajak \\ PEGEMBANGAN HIPOTESIS}

Pajak adalah kontribusi wajib kepada negara yang terutang oleh orang pribadi atau badan yang bersifat memaksa berdasarkan Undang-Undang, dengan tidak mendapatkan imbalan secara langsung dan digunakan untuk keperluan negara bagi sebesar besarnya kemakmuran rakyat. Pembayaran pajak merupakan perwujudan dari kewajiban kenegaraan dan peran serta Wajib Pajak untuk secara langsung dan bersama-sama melaksanakan kewajiban perpajakan untuk pembiayaan negara dan pembangunan nasional. Sesuai falsafah undangundang perpajakan, membayar pajak bukan hanya merupakan kewajiban, tetapi merupakan hak dari setiap warga Negara untuk ikut berpartisipasi dalam bentuk peran serta terhadap pembiayaan negara dan pembangunan nasional (Ayza, 2017).

Tanggung jawab atas kewajiban pembayaran pajak, sebagai pencerminan kewajiban kenegaran di bidang perpajakan berada pada anggota masyarakat sendiri untuk memenuhi kewajiban tersebut. Hal tersebut sesuai dengan sistem self assessment yang dianut dalam Sistem Perpajakan Indonesia. Pemerintah dalam hal ini Direktorat Jenderal Pajak, sesuai dengan fungsinya berkewajiban melakukan pembinaan/penyuluhan, pelayanan, dan pengawasan. Dalam melaksanakan fungsinya tersebut, Direktorat Jenderal Pajak berusaha sebaik mungkin memberikan pelayanan kepada masyarakat sesuai visi dan misi Direktorat Jenderal Pajak (Indriyani \& Sukartha, 2014).

\subsection{PPh 21}

$\mathrm{PPh}$ pasal 21 menurut Peraturan Direktur Jenderal Pajak Nomor PER-32/PJ/2015 adalah pajak atas penghasilan berupa gaji, upah, honorarium, tunjangan dan pembayaran lain dengan nama dan dalam bentuk apapun yang sehubungan dengan pekerjaan atau jabatan, jasa, dan kegiatan yang dilakukan oleh orang pribadi subjek pajak dalam negeri. Berdasarkan Peraturan Direktur Jenderal Pajak No. PER-16/PJ/2016, tarif PPh 21 adalah pajak atas penghasilan berupa gaji, upah honorarium, tunjangan, dan pembayaran lainnya dengan nama dan dalam bentuk apa pun sehubungan dengan pekerjaan atau jabatan, jasa, dan kegiatan yang dilakukan oleh orang pribadi sebagai subjek pajak dalam negeri 
(Retnani, 2016).

Subjek PPh Pasal 21, menurut UU Nomor 36 Tahun 2008, yaitu:

a. Orang Pribadi (OP)

1) Orang Pribadi (OP) Dalam Negeri Yaitu orang pribadi yang bertempat tinggal/ berada di Indonesia lebih dari 183 (seratus delapan puluh tiga) hari dalam 12 (dua belas) bulan, atau dalam suatu tahun pajak berada di Indonesia dan mempunyai niat bertempat tinggal di Indonesia.

2) Orang Pribadi (OP) Luar Negeri Yaitu orang pribadi yang tidak bertempat tinggal/ berada di Indonesia tidak lebih dari 183 (seratus delapan puluh tiga) hari dalam 12 (dua belas) bulan.

b. Badan Yaitu badan yang didirikan atau bertempat kedudukan di Indonesia, kecuali unit tertentu dari badan pemerintah.

c. Warisan yang belum terbagi Yaitu warisan yang belum terbagi sebagai satu kesatuan menggantikan yang berhak.

d. Bentuk Usaha Tetap (BUT) Adalah bentuk usaha yang dipergunakan oleh orang pribadi yang tidak bertempat tinggal di Indonesia, dan badan yang tidak didirikan dan tidak bertempat kedudukan di Indonesia untuk menjalankan usaha atau melakukan kegiatan di Indonesia.

Menurut Peraturan Dirjen Pajak PER16/PJ/2016 Pasal 5 Ayat (1) dan (2), Penghasilan yang dipotong PPh Pasal 21, yaitu (Direktorat, 2016):

1) Penghasilan yang diterima atau diperoleh pegawai tetap, baik berupa Penghasilan yang bersifat teratur maupun tidak teratur.

2) Penghasilan yang diterima atau diperoleh penerima pensiun secara teratur berupa uang pensiun atau penghasilan sejenisnya.

3) Penghasilan berupa uang pesangon, uang manfaat pensiun, tunjangan hari tua, atau jaminan hari tua yang dibayarkan sekaligus, yang pembayarannya melewati jangka waktu 2 (dua) tahun sejak pegawai berhenti bekerja.

4) Penghasilan Pegawai Tidak Tetap atau Tenaga Kerja Lepas, berupa upah harian, upah mingguan, upah satuan, upah borongan, atau upah yang dibayarkan secara bulanan.

5) Imbalan kepada Bukan Pegawai, antara lain berupa honorarium, komisi, fee, dan imbalan sejenisnya dengan nama dan dalam bentuk apapun sebagai imbalan sehubungan jasa yang dilakukan.

6) Imbalan kepada peserta kegiatan, antara lain berupa uang saku, uang representasi, uang rapat, honorarium, hadiah atau penghargaan dengan nama dan dalam bentuk apapun, dan imbalan sejenis dengan nama apapun.

7) Penghasilan berupa honorarium atau imbalan yang bersifat tidak teratur yang diterima atau diperoleh anggota dewan komisaris atau dewan pengawas yang tidak merangkap sebagai pegawai tetap pada perusahaan yang sama.

8) Penghasilan berupa jasa produksi, tantiem, gratifikasi, bonus, atau imbalan lain yang bersifat tidak teratur yang diterima atau diperoleh mantan pegawai.

9) Penghasilan berupa penarikan dana pensiun oleh peserta program pensiun yang masih berstatus sebagai pegawai dari dana pensiun yang pendiriannya telah disahkan oleh Menteri Keuangan.

10) Penerimaan dalam bentuk natura dan/atau kenikmatan lainnya dengan nama dan dalam bentuk apapun yang diberikan oleh:

a) Wajib Pajak yang dikenakan Pajak Penghasilan $(\mathrm{PPh})$ yang bersifat final.

b) Wajib Pajak yang dikenakan Pajak Penghasilan (PPh) berdasarkan norma penghitungan khusus (deemed profit).

Menurut Peraturan Dirjen Pajak PER16/PJ/2016 Pasal 3, Penerima Penghasilan yang dipotong PPh Pasal 21, yaitu (Direktorat, 2016):

1) Pegawai.

2) Penerima uang pesangon, pensiun atau uang manfaat pensiun, tunjangan hari tua, atau jaminan hari tua, termasuk ahli warisnya.

3) Bukan Pegawai yang menerima atau memperoleh penghasilan sehubungan dengan pemberian jasa.

4) Anggota Dewan Komisaris atau Dewan Pengawas yang tidak merangkap sebagai pegawai tetap pada perusahaan yang sama.

5) Mantan Pegawai.

6) Peserta Kegiatan yang menerima atau memperoleh penghasilan sehubungan dengan keikutsertaannya dalam suatu kegiatan.

\section{Penghasilan Kena Pajak}

Penghasilan kena pajak $\mathrm{PPh}$ Pasal 17 dihitung dari penghasilan kotor dikurangi biaya untuk mendapatkan, menagih, dan memelihara penghasilan. Seandainya dalam penghitungan penghasilan kena pajak, penghasilan kotor setelah dikurangi biaya untuk mendapatkan, menagih, dan memelihara penghasilan hasilnya rugi, maka perlu diganti dengan penghasilan pada tahun pajak berikutnya berturut-turut hingga lima tahun. Penghasilan Kena Pajak, menurut Undang-Undang Nomor 36 Tahun 2008 (Repubik Indonesia, 2008) Pasal 6 ayat (1) adalah penghasilan wajib pajak dalam negeri dan bentuk usaha tetap yang ditentukan 
berdasarkan penghasilan bruto dikurangi biaya untuk mendapatkan, menagih, dan memelihara penghasilan dalam satu tahun pajak (Tahar \& Sandy, 2012).

Dengan kata lain Penghasilan Kena Pajak (PKP) adalah penghasilan wajib pajak yang menjadi dasar menghitung pajak penghasilan dalam suatu tahun pajak dihitung dengan cara mengurangkan dari penghasilan, dimana setiap wajib pajak yang telah mempunyai penghasilan wajib untuk membayar pajak dan menghitung pajak sesuai dengan undang-undang dan peraturan perpajakan (Direktorat Jendral Pajak, 2013). 
Tabel 1. Tarif Penghasilan Kena Pajak (PKP) WP Orang Pribadi Dalam Negeri

\begin{tabular}{|c|c|c|c|}
\hline \multirow{4}{*}{ No } & \multirow{4}{*}{$\begin{array}{l}\text { Penghasilan Kena } \\
\text { Pajak (PKP) }\end{array}$} & \multicolumn{2}{|l|}{ Tarif } \\
\hline & & Memiliki & Tidak \\
\hline & & NPWP & Memiliki \\
\hline & & & NPWP \\
\hline 1 & $\begin{array}{l}\text { Sampai dengan Rp } \\
50 \text { Juta }\end{array}$ & $5 \%$ & $6 \%$ \\
\hline 2 & $\begin{array}{l}\text { Rp } 50 \text { juta s/d } 250 \\
\text { juta }\end{array}$ & $15 \%$ & $18 \%$ \\
\hline 3 & $\begin{array}{l}\text { Rp } 250 \text { juta s/d } 500 \\
\text { juta }\end{array}$ & $25 \%$ & $30 \%$ \\
\hline 4 & Di atas Rp 500 juta & $30 \%$ & $36 \%$ \\
\hline
\end{tabular}

Berdasarkan UU Nomor 36 Tahun 2008 Pasal 21 Ayat (5a), tentang besarnya tarif Penghasilan Kena Pajak (PKP) bagi Wajib Pajak (WP) yang tidak memiliki NPWP lebih tinggi $20 \%$ (dua puluh persen) daripada tarif yang diterapkan terhadap WP yang dapat menunjukkan NPWP (Repubik Indonesia, 2008).

\section{Insentif PPh Pasal 21}

Penghasilan yang diterima Pegawai wajib dipotong sesuai ketentuan PPh Pasal 21 oleh Pemberi Kerja, dan berdasarkan Peraturan Menteri Keuangan Nomor 44/PMK.03/2020 Pasal 2 Ayat 2, PPh Pasal 21, penghasilan pegawai yang sudah dipotong sesuai ketentuan perpajakan oleh Pemberi Kerja akan ditanggung oleh Pemerintah atas penghasilan yang diterima Pegawai dengan kriteria tertentu. Insentif $\mathrm{PPh}$ Pasal 21 yang ditanggung Pemerintah (DTP) ini hanya berlaku selama 6 (enam) bulan terhitung sejak Masa Pajak April 2020 sampai dengan Masa Pajak September 2020 (H. Safitri, 2021).

Kriteria tertentu tersebut meliputi: (a) Wajib Pajak (WP) menerima atau memperoleh penghasilan dari Pemberi Kerja yang memiliki kode Klasifikasi Lapangan Usaha (KLU) sesuai ketentuan perpajakan, sebagai Perusahaan Kemudahan Impor Tujuan Ekspor (KITE), memiliki izin Penyelenggaraan Kawasan Berikat, atau izin Pengusaha Dalam Kawasan Berikat (PDKB), (b) Wajib Pajak (WP) memiliki Nomor Pokok Wajib Pajak (NPWP), dan (c) Wajib Pajak (WP) memiliki Penghasilan Bruto yang bersifat tetap dan teratur pada Masa Pajak menerima atau memperoleh tidak lebih dari Rp.200.000.000,(dua ratus juta rupiah) (Aji, 2020). Untuk mendapatkan insentif pajak ada beberapa hal yang perlu dilakukan oleh Pemberi Kerja, yaitu: (a) Pemberi Kerja dapat menyampaikan pemberitahuan kepada Kepala Kantor Pelayanan Pajak (KPP) tempat Pemberi Kerja terdaftar melalui www.pajak.go.id, (b) Pemberi Kerja menyampaikan pemberitahuan kepada Kepala Kantor Pelayanan Pajak (KPP) untuk memanfaatkan insentif PPh Pasal 21 yang ditanggung Pemerintah sesuai dengan ketentuan perpajakan yang berlaku, (c) Pemberi Kerja harus menyampaikan laporan realisasi $\mathrm{PPh}$ Pasal 21 ditanggung Pemerintah melalui www.pajak.go.id, dan (d) Pemberi Kerja harus membuat Surat Setoran Pajak (SSP) atau cetakan kode billing atas PPh Pasal 21 ditanggung Pemerintah (Marlina \& Syahribulan, 2021).

\section{METODE PENELITIAN}

Pengamatan secara langsung terhadap objek riset yaitu Wajib Pajak (WP) yang mendapatkan Insentif Pajak Penghasilan (PPh) Pasal 21 yang ditanggung Pemerintah (DTP) di Kantor Pelayanan Pajak (KPP) Pratama Denpasar Timur di Jalan Tantular No. 4, Denpasar.

Penelitian ini menggunakan data kuantitatif dan kualitatif yang bersumber dari artikel ilmiah, undang-undang dan peraturan perpajakan, dan buku mengenai teori dan mekanisme prosedur penghitungan PPh Pasal 21 pada saat pandemi Covid19 di Indonesia, yang dapat dijadikan sebagai dasar penelitian yang berkelanjutan. nalisis data dilakukan menggunakan tiga tahapan teknik menganalisis data berupa (1) data dikumpulkan, (2) pengurangan data dan (3) mengambil kesimpulan dari penelitian

\section{HASIL DAN PEMBAHASAN Prosedur Penghitungan PPh Pasal 21}

Menurut Perpu Nomor 1 Tahun 2020 (H. R. Safitri et al., 2021) Pemerintah telah mengeluarkan Peraturan Pemerintah Pengganti Undang-Undang Republik Indonesia Nomor 1 Tahun 2020 tentang Kebijakan Keuangan Negara dan Stabilitas Sistem Keuangan untuk Penanganan Pandemi Corona Virus Disease 2019 (COVID-19) dan/atau Dalam Rangka Menghadapi Ancaman yang Membahayakan Perekonomian Nasional dan/ata Stabilitas Sistem Keuangan. Perppu ini memuat berbagai kebijakan keuangan negara, termasuk bidang perpajakan, dan sektor keuangan demi mencegah keadaan krisis akibat wabah virus Korona.

Pajak Penghasilan (PPh) pasal 21, menurut Peraturan Direktur Jenderal Pajak Nomor PER16/PJ/2016 adalah pajak atas penghasilan berupa gaji, upah, honorarium, tunjangan dan pembayaran lain dengan nama dan dalam bentuk apapun yang sehubungan dengan pekerjaan atau jabatan, jasa, dan kegiatan yang dilakukan oleh orang pribadi subyek pajak dalam negeri (Erica \& Vidada, 2020).

Prosedur penghitungan Pajak Penghasilan $(\mathrm{PPh})$ Pasal 21 Ditanggung Pemerintah (DTP), dapat dicontohkan dengan perhitungan sederhana berikut:

\section{Contoh Kasus 1}

Tuan Budi (K/1) sebagai pegawai tetap di PT. XYZ (industri makanan bayi/KLU 10791), pada bulan April 
2020 menerima gaji dan tunjangan sebesar Rp. 15.000.000,- dan membayar iuran pensiun sebesar Rp. 300.000,- dan jika di setahunkan penghasilan Tuan Budi menjadi Rp. 180.000.000,- dan menurut ketentuan perpajakan yang berlaku Tuan Budi mendapatkan insentif PPh Pasal 21 DTP dikarenakan jumlah penghasilan setahun masih dibawah Rp. 200.000.000,-

\section{Perhitungan PPh Pasal 21 terutang Tuan Budi di} bulan April 2020:

Gaji dan Tunjangan

Pengurangan:

B. Jabatan

Iuran Pensiun

Penghasilan Neto sebulan

Penghasilan Neto setahun:

12x Rp.15.800.000,189.600.000,-

PTKP $(\mathrm{K} / 1)$

63.000.000,-)

PKP Setahun

126.600.000,-

Rp.15.000.000,-

Rp. 500.000,-

Rp. 300.000,-

Rp. 800.000,-

Rp.15.800.000,-

Rp.

(Rp.

Rp.

PPh Pasal 21 Terutang Setahun:

$5 \%$ x R. $50.000 .000=$

$15 \%$ xRp. $76.600 .000=$

RP. 11.490.000,-

$\mathrm{Rp}$.

13.990.000,-

PPh Pasal 21 Terutang Sebulan:

Rp. 13.990.000,- / $12=\quad$ Rp. 1.165.833,-

Maka besarnya penghasilan yang diterima Tuan Budi pada bulan April 2020, adalah:

Gaji dan Tunjangan

Rp.15.000.000,-

Iuran Pensiun/bulan

(Rp. 300.000,-)

$\mathrm{PPh}$ Pasal 21

(Rp. 1.165.833,)

Penghasilan setelah pajak Rp. 13.534.167,-

PPH Pasal 21 (DTP)

Jumlah yang diterima

Rp. 1.165.883,-

Rp. 14.700.050,

\section{Contoh Kasus 2}

Tuan Eko (K/0) adalah pegawai tetap di PT. XYZ (industri makanan bayi/KLU 10791), pada bulan Mei 2020 menerima gaji dan tunjangan sebesar Rp. 22.000.000,- dan membayar iuran pensiun sebesar Rp. 440.000,- sedangkan penghasilan Tuan Eko jika di setahunkan menjadi Rp. 264.000.000,- sehingga PPh Pasal 21 terutang pada bulan Mei 2020 untuk Tuan Eko tidak mendapatkan insentif PPh Pasal 21 DTP, dikarenakan penghasilan Tuan Eko dalam setahun lebih dari Rp. 200.000.000,-

Berdasarkan dari data di lapangan menurut (Sariwati, 2021) pemungutan pajak harus efesien: Biaya-biaya yang dikeluarkan dalam rangka pemungutan pajak harus diperhitungkan. Jangan sampai pajak yang diterima lebih rendah daripada biaya pengurusan pajak tersebut. Oleh karena itu, sistem pemungutan pajak harus sederhana dan mudah untuk dilaksanakan. Dengan demikian, wajib pajak tidak akan mengalami kesulitan dalam pembayaran pajak baik dari segi penghitungan maupun dari segi waktu.

Perhitungan PPh Pasal 21 terutang Tuan Eko di bulan Mei 2020:

Gaji dan Tunjangan

Rp.22.000.000,-

Pengurangan:

B. Jabatan Rp. 500.000,-

Iuran Pensiun

Penghasilan Neto sebulan

Penghasilan Neto setahun:

12x Rp.22.940.000,- $\quad$ Rp. 275.280.000,-

PTKP (K/0) (Rp. 58.500.000,-)

PKP Setahun Rp. 333.780.000,-

\section{PPh Pasal 21 Terutang Setahun:}

$$
\begin{array}{ll}
5 \% \times \mathrm{Rp} .50 .000 .000= & \text { Rp. } 2.500 .000,- \\
15 \% \times \mathrm{Rp} .250 .000 .000= & \text { RP. } 37.500 .000,- \\
25 \% \times \text { Rp. } 33.780 .000= & \text { Rp. } 8.445 .000,- \\
& \text { Rp. } 48.445 .000,-
\end{array}
$$

\section{PPh Pasal 21 Terutang Sebulan:}

$$
\text { Rp. 48.445.000,- } / 12=\quad \text { Rp. 4.037.083, }
$$

\section{Contoh Kasus 3}

Tuan Fathur $(K / 1)$ adalah pegawai tetap di PT. XYZ (industri makanan bayi/KLU 10791), pada bulan Mei 2020 menerima gaji dan tunjangan sebesar Rp. 14.000.000 dan membayar pensiun sebesar Rp. 280.000,- dan menerima Tunjangan Hari Raya (THR) sebesar Rp. 11.000.000,- sedangkan penghasilan bruto Tuan Fathur atas penghasilan tetap dan teratur berupa gaji dan tunjangan jika di setahunkan sebesar Rp. 168.000.000,- dan Tuan Fathur mendapatkan insentif PPh Pasal 21 DTP namun hanya untuk penghasilan gaji dan tunjangan yang bersifat tetap dan teratur setiap bulannya.

Perhitungan PPh Pasal 21 terutang bulan Mei 2020:

Gaji dan Tunjangan Rp.14.000.000,-

Pengurangan:

B. Jabatan Rp. 500.000,-

Iuran Pensiun Rp. 280.000,- p. 780.000,-

Penghasilan Neto sebulan Rp.14.780.000,-

Penghasilan Neto setahun:

12x Rp.14.780.000,- Rp. 177.360.000,-

PTKP (K/1) (Rp. 63.000.000,-)

PKP Setahun Rp. 114.360.000,-

PPh Pasal 21 Terutang Setahun:

$5 \%$ x Rp.50.000.000 = Rp. 2.500.000,-

$15 \%$ xRp.64.360.000 = RP. 9.654.000,-

PPh Pasal 21 setahun Rp. 12.154.000,-

PPh Pasal 21 Terutang Sebulan:

Rp. 12.990.000,- / 12 = Rp. 1.082.500,-

Maka atas PPh Pasal 21 DTP sebesar Rp. 1.082.500,- 
diserahkan oleh Pemberi Kerja kepada Tuan Fathur

Penghitungan PPh Pasal 21 terutang atas THR Tuan Fathur bulan Mei 2020

Gaji dan tunjangan setahun Rp. 168.000.000,-

THR Rp. 11.000.000,-

Penghasilan bruto Rp.179.000.000,-

Pengurangan:

Biaya Jabatan Rp.6.000.000,-

Iuran Pensiun Rp.3.360.000,-

Pengasilan Neto Rp.188.360.000,-

PTKP (K/1)Rp. 63.000.000,-

PKP Setahun Rp.125.360.000,-

PPh Pasal 21 Terutang Setahun:

$5 \%$ xRp. $50.000 .000=$ Rp. 2.500 .000 ,-

$15 \%$ xRp. $75.360 .000=\mathrm{Rp}$.

11.304.000,Rp.13.804.000,-

\section{PPh Pasal 21 atas THR:}

PPh Pasal 21 atas seluruh Penghasilan

(Gaji,Tunjangan, dan THR) Rp. 13.804.000,-

PPh Pasal 21 atas penghasilan tetap (Gaji dan

Tunjangan) (Rp. 12.154.000,-)

PPh Pasal 21 atas THRRp. 1.650.000,-

Maka Pemberi Kerja memotong dan menyetorkan

PPh Pasal 21 atas THR Tuan Fathur sebesar Rp.

1.650.000,-

Besarnya penghasilan yang diterima Tuan

Fathur bulan Mei 2020:

Gaji dan Tunjangan Rp. 14.000.000,-

THR Rp. 11.000.000,-

Iuran Pensiun/bulam (Rp. 280.000,-)

PPh Pasal 21 atas seluruh Penghasilan

Rp.13.804.000/ 12 (Rp. 1.150.333,-)

Penghasilan setelah pajak Rp. 23.569.667,-

Ditambah PPh Psl 21 DTP Rp. 1.082.500,-

Jumlah yang diterima Rp. 24.652.167,-

Dari beberapa contoh kasus di atas, diharapkan untuk Wajib Pajak (WP) pekerja tetap yang terdampak Covid-19 dapat menghitung sendiri perhitungan Pajak Penghasilan (PPh) Pasal 21 secara mandiri, selain itu untuk melihat apakah penghasilan dari Wajib Pajak (WP) dalam setahun jumlahnya memenuhi salah satu ketentuan perpajakan untuk menerima insentif PPh Pasal 21 DTP, dimana pemerintah akan menanggung PPH Pasal 21 Wajib Pajak (WP) yang telah memenuhi ketentuan perpajakan.

Kebijakan Pajak Indonesia dalam masa Pandemi COVID-19, kebijakan diterbitkan yang diberlakukan untuk dapat menjaga tercapai perolehan dana dari pajak dan efektivitas pengumpulannya. Salah satu kebijakan pajak adalah penetapan tarif pajak, maka perlu untuk membuat kebijakan oleh pemerintah atas penetapan tarif pajak yang sesuai atau efektif yang berimbas positif terhadap nilai investasi. Harapannya untuk menahan dampak pandemi virus corona pada ekonomi Indonesia. Pemerintah telah mengeluarkan 14 pernyataan kebijakan pajak dirangkum oleh data yang dikeluarkan OECD diantaranya berkaitan tentang pengurangan tarif pajak penghasilan badan, penangguhan pembayaran pajak, tingkat limit restitusi, penangguhan pembayaran pajak, keringanan pajak, dan lainnya berkaitan tentang perpajakan pada masa pandemi COVID-19. Dari 14 pernyataan tersebut tertuang dalam Peraturan Pemerintah (PP), Peraturan Menteri Keuangan (PMK) dan Peraturan Direktur Jenderal Pajak (PER Dirjen Pajak) (Padyanoor, 2020).

\section{KESIMPULAN}

Manfaat dari penelitian ini untuk membantu masyarakat umum dan khususnya Wajib Pajak (WP) Orang Pribadi untuk dapat menghitung Pajak Penghasilan (PPh) Pasal 21 secara mandiri, terutama untuk memastikan apakah Wajib Pajak (WP) tersebut bisa mendapatkan Insentif PPh Pasal 21 DTP yang dapat membantu meringankan beban ekonomi yang terdampak dari penyebaran wabah Covid-19 di Indonesia. Meskipun kebijakan pemerintah dalam hal pemberian insentif pajak ini memiliki konsekuensi terhadap penurunan atas penerimaan negara dari sektor pajak. Namun kebijakan tersebut dapat mengurangi efek domino yang diakibatkan oleh adanya pandemi Covid19 terhadap perekonomian nasional.

Sebagai saran untuk Wajib Pajak (WP) Orang Pribadi telah memenuhi ketentuan Peraturan Menteri Keuangan Nomor 44/PMK.03/2020, untuk dapat memanfaatkan kebijakan pemerintah terkait dengan Insentif PPh Pasal 21 DTP sebagai salah satu bentuk stimulus fiskal yang dapat membantu dalam percepatan perbaikan perkonomian dan pembangunan nasional di tengah wabah Covid-19 di Indonesia. Selain itu hasil dari penelitian ini dapat dijadikan sebagai dasar penelitian yang berkelanjutan.

\section{REFERENSI}

Aji, I. P. (2020). Tinjauan Insentif PPH Bagi SDM di Bidang Kesehatan Dalam Masa Pandemi Virus Covid-19. Behavioral Accounting Journal, 3(2), https://doi.org/10.33005/baj.v3i2.105

Aqmarina, F. (2020). Peran Pajak Sebagai Instrumen Kebijakan Fiskal Dalam Mengantisipasi Krisis Ekonomi. 03(02), 20.

Ayza, B. (2017). Hukum Pajak Indonesia. Kencana. Direktorat, J. P. (2016). Peraturan Direktur Jenderal Pajak Nomor Per-16/PJ/2016. Kementerian Keuangan. 
Direktorat Jendral Pajak. (2013). Pajak Penghasilan $\quad(P P h) . \quad$ Kementerian Keuangan.

Erica, D., \& Vidada, I. A. (2020). Prosedur Penghitungan Insentif PPh Pasal 21 Pada Saat Pandemi Covid-19 Di Indonesia. 18(2), 8.

Fitri, W. (2020). Implikasi Yuridis Penetapan Status Bencana Nasional Pandemi Corona Virus Disease 2019 (COVID-19) Terhadap Perbuatan Hukum Keperdataan. Jurnal Supremasi Hukum, 9(1).

Hs, H. K., Salahuddin, M., \& Nurhidayati, S. (2020). Konsep Kebijakan Strategis Dalam Menangani Eksternalitas Ekonomi Dari Covid - 19 Pada Masyarakat Rentan Di Indonesia. 10.

Indriyani, P. A., \& Sukartha, I. M. (2014). Tanggungjawab Moral, Kesadaran Wajib Pajak, Sanksi Perpajakan dan Kualitas pelayanan pada kepatuhan pelaporan wajib pajak badan. 13.

Marlina, L., \& Syahribulan, S. (2021). Peranan Insentif Pajak Yang Di Tanggung Pemerintah (DTP) Di Era Pandemi Covid 19. Economy Deposit Journal (E-DJ), 2(2). https://doi.org/10.36090/edj.v2i2.910

Padyanoor, A. (2020). Kebijakan Pajak Indonesia Menanggapi Krisis COVID-19: Manfaat bagi Wajib Pajak. E-Jurnal Akuntansi, 30(9), 2216. https://doi.org/10.24843/EJA.2020.v30.i 09.p04

Pendit, I. P. W. L., Budiarth, I. N. P., \& Widiati, I. A. P. (2017). Kebijakan Pemerintah Dalam Memberikan Insentif Pajak Penghasilan Pasal 21 Kepada Wajib Pajak Terdampak Pandemi Covid-19. Jurnal Konstruksi Hukum, 2(2).

Rahman, A. (2018). Diajukan Sebagai Salah Satu Syarat Untuk Memperoleh Gelar Sarjana Ekonomi Pada Fakultas Ekonomi Universitas Negeri Padang. 20.

Repubik Indonesia. (2008). Undang-Undang Republik Indonesia Nomor 36 Tahun 2008 Tentang Perubahan Keempat Atas Undang-Undang Nomor 7 Tahun 1983 Tentang Pajak Penghasilan. Republik Indonesia.
Retnani, E. D. (2016). Analisis Penerapan Perencanaan Pph 21 Dalam Rangka Meminimalkan PPh BADAN Romualdus Dwasta Sabono. 5, 17.

Safitri, H. (2021). Implementasi Kebijakan PPh21 SelamaPandemi Covid-19 di Provinsi DKI Jakarta. Jurnal Ilmu Administrasi Publik Dan Bisnis, 7.

Safitri, H. R., Yanty, N. A., Adelia, S., Kusumaningtyas, T., \& Sofyan, M. (2021). Implementasi Kebijakan PPh 21 Selama Pandemi Covid-19 di Provinsi DKI Jakarta. Jurnal Ilmu Administrasi Publik Dan Bisnis, l(1), 7.

Sariwati, R. (2021). Kajian yuridis pemberian insentif pajak penghasilan pada masa pandemi Covid-19. Jurnal Cakrawala Hukum, 12(1), 90-98. https://doi.org/10.26905/idjch.v12i1.5722

Tahar, A., \& Sandy, W. (2012). Pengaruh Persepsi Wajib Pajak Atas Pelayanan Kpp, Sanksi Perpajakan Dan Pengetahuan Atas Penghasilan Kena Pajak Terhadap Kepatuhan Wajib Pajak. Jurnal Akuntansi dan Investasi, 12.

Wiryawan, I. W. (2019). Kebijakan pemerintah dalam penanganan pandemi virus corona disease 2019 (covid-19) di indonesia. 10. 